\title{
Critical Information Literacy in Practice: A Bibliographic Review Essay of Critical Information Literacy, Critical Library Pedagogy Handbook, and Critical Literacy for Information Professionals
}

Lua Gregory

University of Redlands, lua_gregory@redlands.edu

Shana Higgins

University of Redlands, shana_higgins@redlands.edu

Follow this and additional works at: https://pdxscholar.library.pdx.edu/comminfolit

Part of the Information Literacy Commons

Let us know how access to this document benefits you.

\section{Recommended Citation}

Gregory, L., \& Higgins, S. (2017). Critical Information Literacy in Practice: A Bibliographic Review Essay of Critical Information Literacy, Critical Library Pedagogy Handbook, and Critical Literacy for Information Professionals. Communications in Information Literacy, 11 (2), 390-403. https://doi.org/10.15760/ comminfolit.2017.11.2.10 


\section{Critical Information Literacy in Practice: A Bibliographic Review Essay of Critical Information Literacy, Critical Library Pedagogy Handbook, and Critical Literacy for Information Professionals}

Lua Gregory, University of Redlands

Shana Higgins, University of Redlands

Keywords: critical information literacy; critical pedagogy; critical theory; critical literacy; praxis; book review

\section{Book Review essay edited by Merinda McLure \& Robert Schroeder}

Gregory, L., \& Higgins, S. (2017). Critical information literacy in practice: A bibliographic review essay of Critical Information Literacy, Critical Library Pedagogy Handbook, and Critical Literacy for Information Professionals. Communications in Information Literacy, 11(2), 390-403.

Copyright for articles published in Communications in Information Literacy is retained by the author(s). Author(s) also extend to Communications in Information Literacy the right to redistribute this article via other scholarly resources and bibliographic databases. This extension allows the authors' copyrighted content to be included in some databases that are distributed and maintained by for-profit companies. All other rights of redistribution are licensed by Communications in Information Literacy under Creative Commons Attribution-NonCommercial-ShareAlike 4.0 International (CC BYNC-SA 4.0). 


\section{Critical Information Literacy in Practice: A Bibliographic} Review Essay of Critical Information Literacy, Critical Library Pedagogy Handbook, and Critical Literacy for Information Professionals

Recent publications demonstrate that librarians are actively developing a critical practice, a critical information literacy (CIL). The early threads of CIL scholarship are found in the work of Pawley (1998, 2003), Luke and Kapitzke (1999), Kapitzke (2003), Swanson (2004), Doherty (2005, 2007), Simmons (2005), Anderson (2006), Doherty and Ketchner (2005), Elmborg (2006), Whitworth (2006), Jacobs (2008), and others who point out the "social, political, and ideological construction of knowledge” (Luke \& Kapitzke, 1999, p. 481) and the power of praxis in developing a transformative practice. Texts such as Critical Library Instruction: Theories and Methods (Accardi, Drabinski, \& Kumbier, 2010) and Critical Theory for Library and Information Science: Exploring the Social from Across the Disciplines (Leckie, Given, \& Buschman, 2010) mark a growing interest among librarians in bringing critical theory into practice. Subsequent texts, such as Feminist Pedagogy for Library Instruction (Accardi, 2013), Information Literacy and Social Justice: Radical Professional Praxis (Gregory \& Higgins, 2013) and Informed Agitation: Library and Information Skills in Social Justice Movements and Beyond (Morrone, 2013), all limn the social justice orientations of critical librarianship. CIL scholarship has been further developed by Reale (2012), Beilin and Leonard (2013), Hicks (2013), Smith (2013), Beatty (2014), Drabinski (2014), Nicholson (2014), Schlesselmann-Tarango (2014), Schroeder (2014), and \#critlib conversations. ${ }^{1}$ We are seeing a quickening of scholarship on CIL and Eamon Tewell, in "A Decade of Critical Information Literacy: A Review of the Literature," (2015) remarks that "the literature of critical information literacy and librarianship gives no indication of slowing its pace” (p. 36).

In Critical Information Literacy: Foundations, Inspiration, and Ideas (Downey, 2016), the twovolume Critical Library Pedagogy Handbook (Pagowsky \& McElroy, 2016), and Critical Literacy for Information Professionals (McNicol, 2016), we find the exploration, continuation, and maturation of critical pedagogy in librarianship and critical information literacy. Inspired by James Elmborg, many of the librarians included in these four texts are taking up "the real task for libraries in treating information literacy seriously" by "developing a critical practice of librarianship-a theoretically informed praxis" (Elmborg, 2006, p. 198). These volumes demonstrate diverse approaches to, and diverse interpretation and practice of CIL in 
librarianship. In this diversity, we nonetheless see common threads in relation to conscientization $^{2}$ as teaching librarians, theories and theorists, praxis, and obstacles and opportunities in practicing critical pedagogy in information literacy.

Downey's revised dissertation provides a good entry into the subject of CIL. The subtitle to the book, Foundations, Inspirations, and Ideas, signals that the purpose of the text is to provide "inspiration, foundational knowledge, and tools" to develop a critical information literacy practice (p. 27). Using interview data collected from 2012 to 2013 for dissertation research, Downey examines the experiences of academic librarians practicing CIL in higher education, in order to illustrate the application of critical pedagogy, the integration of critical content, and individual and institutional obstacles to the practice of critical librarianship. Downey states that her book answers Elmborg's question: Is the library "a passive information bank where students and faculty make knowledge deposits and withdrawals, or is it a place where students engage existing knowledge and shape it to their own current and future uses?" (Elmborg, as cited in Downey, p. 26).

The introduction to Critical Information Literacy: Foundations, Inspiration, and Ideas is authored by Jessica Critten and it clearly sets and defines aspirations for CIL as "a call for resistance and change" (p. 6). Downey responds to this call by problematizing standardsbased information literacy, suggesting that mechanistic, resource-based approaches to library instruction are too superficial to be considered teaching information literacy (p. 51 52). Downey proposes critical pedagogy as an alternative to standards-based IL and introduces pedagogues and their theories. For Downey, Paulo Freire's theory of critical pedagogy and Jack Mezirow's theory of transformative learning are both examples of experiential education (p. 44), and have influenced the development of CIL.

The transformative and liberatory aims of critical pedagogy can be inspiring and in chapter 3, "The Revelatory Power of CIL," Downey draws on interview data to explore this experience of inspiration on the part of librarians. We learn from interviewees that they were inspired by the possibilities of CIL through their discovery of works by librarian scholars such as James Elmborg, Heidi L. M. Jacobs, Maria Accardi, Emily Drabinski, Alana Kumbier, Allan Luke, Cushla Kaptizke, and Troy Swanson (p. 70). Downey writes that discovering CIL "fills their [librarians'] desire to find more meaning in their work, becoming a major source for motivation and inspiration” (p. 71). In terms of professional identity, librarians who embrace critical theory "are invested in the broad project of social justice and believe their professional work should improve their students' lives and society" (p. 76). The interview data from Downey's dissertation research is woven throughout the 
rest of the chapters, providing especially illuminating examples when Downey discusses the teaching methods of critical librarians in chapter 4, and in course content in chapter 5. Throughout the book, Downey highlights the challenges that critical librarians encounter in their practice, such as the inadequacy of one-shots (p. 99); a lack of time (p. 97, 99, 128-129); limited resources; turf, or "librarians' reluctance to be seen as intruding on faculty territory" (p. 129); the pressures of practicality (p. 158-160); and the expectations of standardization and assessment (p. 162-164).

Since Downey's qualitative research involves interview testimony from academic librarians, the project feels personal. Interviewees share honest thoughts and experiences as they work through questions, challenges, and experiments to discover, adopt, and practice applying critical theory in their work in higher education. Downey has captured a snapshot in the development of CIL within academic librarianship. However, since this interview data was collected in 2012 and 2013, more recent conversations regarding CIL and the ACRL Framework (2015) are missing from this volume. Nonetheless, the questions and challenges experienced by academic librarians when engaging with critical practice continue to be relevant. Downey's book will inspire librarians who are interested in CIL; the author also presents a useful introduction for readers who are new to the subject.

If we consider that Downey's book provides foundational knowledge concerning CIL, then Pagowsky and McElroy's Critical Library Pedagogy Handbook, and likewise McNicol's Critical Literacy for Information Professionals, demonstrate a continuation and evolution of CIL in practice. Pagowsky and McElroy have compiled an extensive resource, spanning just over 500 pages, which will serve to aid primarily academic librarians who hope to understand critical theory and critical pedagogy within the profession. Critical Library Pedagogy Handbook Volume 1 begins with a foreword by James Elmborg, who provides a brief account of the history of critical theory "as an alternative to empiricism and analytical approaches to knowledge production" (p. vii). Elmborg describes this work as demonstrating "the breadth of experimentation going on in libraries about how to do critical pedagogy" (p. xi). This "breadth of experimentation" is evident in the collection of 30 essays and workbook activities in Volume 1, and in the 30 lesson plans in Volume 2, which cover subjects such as antiracist pedagogy, authority, assessment, challenges to teaching CIL, critical questioning, critical consciousness, feminist pedagogy, gender, hip hop, human rights, popular culture, power, privilege, punk rock, reflection, resistance, social justice, standards, and zines. 
The authors in Volume 2 share ways in which they have integrated CIL into their teaching practice, curriculum, and program planning despite the often contingent nature of their teaching. These authors seem to be responding to the concern voiced by one of Downey's interviewees, anxious about proving institutional value, who shared that a primary reason that "critical information literacy had not taken root in the profession was because it is not possible to demonstrate learning outcomes with it ... so I don't think its time has come yet" (p. 164). Each lesson plan in Volume 2 includes learning outcomes, an introduction to the topics covered in the lesson, teaching materials, notes on preparation, step-by-step instructions for teaching, recommendations for assessment, the lesson author's reflections on teaching the session, and final questions for the reader. Some lesson plans also include an appendix of handouts, contributing to the usefulness of this volume for librarians who may be looking for practical examples of teaching CIL. We agree with Safiya Umoja Noble, who affirms in the foreword to Volume 2 that "if there were ever a time for critical information instruction, the time is now" (p. vii).

The use of learning outcomes and assessment shows attempts by librarians to weave CIL into the current culture of assessment in higher education. However, this does not mean that tensions regarding assessment are put to rest; rather, critical librarians must still be cognizant of the reasons for assessment, working to design tools that benefit students and assist us in our roles as teachers. Two chapters explore tensions related to assessment and critical practice. Carolyn Caffrey Gardner and Rebecca Halpern discuss the worrisome connections between neoliberalism, assessment, standardization, and the commodification of student learning in their chapter, "At Odds with Assessment: Being a Critical Educator within the Academy." They share methods for designing assessment that supports critical practice by considering context and purpose, in order to create assessment that does "the least harm to students" (p. 47). Rachel Gammons' chapter, "Incorporating Critically Conscious Assessment into a Large-Scale Information Literacy Program,” explores an inclusive, reflective, critical assessment practice at the program level. Gammons asks us, as educators and librarians: "What message does your assessment send to your students?" (p. 240).

Just as Downey discusses obstacles encountered by critical librarians; so too do the contributing authors in this collection. Gr Keer, whose chapter "Barriers to Critical Pedagogy in Information Literacy Teaching" is dedicated to this issue, explains that advancing critical pedagogy "means broadening the scope of teaching and learning well beyond the walls of the academy" (p. 67), and that educators must acknowledge and reflect 
on "their own positionality" (p. 67). Additionally, Keer notes that practicing critical pedagogy is time consuming: it "takes time to build trust with disciplinary faculty who control our access to their classroom, and it takes time to build trust with their students" (p. 70). This position is further exacerbated by librarians' lack of time with students in the traditional one-shot.

Several contributing authors consider the dearth of time and the overall inadequacy of the one-shot library instruction model. In "Falling Out of Praxis," Heidi L. M. Jacobs empathizes with the universal lack of time and heavy workloads that librarians experience; however, Jacobs cautions that this may lead librarians to fall back on methods of teaching that replicate the banking model of education and that lack reflection. Lauren Wallis asks, "How can we use critical pedagogy to resist the one-shot?” (p. 6), and Kenny Garcia discusses the limitations of the one-shot model given the time that librarians need to support all of the goals of popular education. Nonetheless, Garcia encourages librarians to focus on developing critical consciousness by supporting students in identifying and analyzing social justice issues. Karen Nicholson continues discussion of the one-shot in “'Taking Back' Information Literacy: Time and the One-Shot in the Neoliberal University.” Nicholson suggests that one-shot instruction models support "corporate time" and that an "intensification of work-associated with a shortage of time-becomes the primary obstacle to developing critical pedagogy" (p. 30). Nicholson recommends slow scholarship as a way to resist "the accelerated, fragmented time of the neoliberal university" (p. 31) and connects neoliberalism to the heavy workloads, shortage of time, and other problems found in academic library work.

Critique lives happily alongside optimism in these volumes, especially in relation to breaking down notions of neutrality and objectivity, de-centering authority, and the social, economic, political, and cultural contexts of information consumption, production, and circulation. Fobazi Ettarh, Gina Schlesselman-Tarango, and Frances Suderman provide lesson plans that help students strip away the veneer of neutrality in media productions. Ettarh creates a space for K-12 students to become critical consumers of advertising, while Schlesselman-Tarango and Suderman use the information cycle to engage undergraduate students in contextualizing the social constructions of blackness, whiteness, and socioeconomic status. Patrick Williams describes archives and special collections as ideal spaces to reveal the mythology of information, libraries, and systems as neutral; in archives, students learn "that systems of publishing, systems of organization, and systems of access are not neutral, naturally occurring, or without specific, contextual strengths and weaknesses” 
(Pagowsky \& McElroy, 2016, Vol. 1, p. 118). Xan Goodman encourages students to question the authority of health sciences terminology by asking them to "interrogate the authority origin story of these terms and how the terms were applied to marginalized groups" (Pagowsky \& McElroy, 2016, Vol. 2, p. 132). Nearly all of the lesson plans in Volume 2 are designed to ask learners to contextualize the production or consumption of information and-in so doing-to question normalized conceptions of authority.

Sarah McNicol's Critical Literacy for Information Professionals is structured similarly to Pagowsky and McElroy's volumes; the first part includes theoretical essays and the second part explores librarians' applications of theory. McNicol writes that the goal of the text is "to help readers to reflect on the significance of critical literacy for libraries and the ways in which they support various user groups," and to share practical applications of critical literacy (p. xii). As in Pagowsky and McElroy's volumes, the book structure mirrors the act of praxis by pairing theory with examples of librarians' practices.

Perhaps the most striking difference between McNicol's book and Pagowsky and McElroy's volumes are the theories and theorists that provide inspiration. The authors in Pagowsky and McElroy's set focus primarily on Paulo Freire, Henry Giroux, and bell hooks. McNicol's book includes Freire, along with a selection of theories that are specific to critical literacy: for instance, reader response theory, new literacy studies, and adult education.

The authors speak to a wider variety of contexts in McNicol's Critical Literacy for Information Professionals. This increases the potential to reach a broader audience; there are chapters exploring critical literacy in public, school, and university library settings. Michael Cherry's chapter describes a public library program to teach incarcerated youth about media literacy. Rebecca Jones, Joel Crowley, and Anthony Tilke's respective chapters each cover critical literacy in K-12 contexts. Several chapters focus on undergraduate students. Alison Hicks dismantles the view that international students are a homogenous group with a problem or deficit to fix. Rachel Elizabeth Scott examines CIL among communication students at the University of Memphis. Sarah Clark shares dissertation research on community college students' search mediation experiences and implications for CIL. Evangelia Bougatzeli and Efi Papadimitriou focus on critical web-literacy in teacher education at Aristotle University of Thessaloniki in Greece.

While authors explore the application of critical literacy in specific contexts, many chapters in McNicol's text could be adapted for implementation in other contexts. McNicol's chapter on comics as a medium through which assumptions and the status quo can be challenged 
focuses on using comics in health-education settings in order to empower patients. This might work well with courses in which students learn to unpack cultural assumptions: for example, ethnic studies courses, or women's, gender, and sexuality studies courses. J. J. Pionke's chapter, “Using New Literacies to Discuss Disability in the Library,” expands on Lankshear and Knobel's work on using mindsets to evaluate libraries (or any building), in order to move people toward a mindset that supports accessibility and universal design. According to Pionke, an "includer" mindset creates a "better user experience," reduces frustration, and "increase[s] understanding and respect" for people with disabilities (p. 63). Libraries are workplaces and Andrew Whitworth envisions communities of practice that support a "collective responsibility" of authority (p. 66), where models of literacy, as well as practices, should be transformed "through a process of enquiry that . . . is irrevocably collective, dialogic, and intersubjective” (p.76).

Criticisms of the one-shot model appear in McNicol's text, as they did in Pagowsky and McElroy's volumes; they are focused on the challenging time constraints for librarians who wish to meet the goals of critical pedagogy. Jessica Critten identifies librarian collaborations with disciplinary faculty as more conducive to student-centered learning than one-shots, with possibilities including the creation of assignments, research consultations, and the instruction of credit-bearing courses. Jennifer Lau-Bond, in the chapter "Social Justice, Adult Learning and Critical Literacy," echoes the one-shot challenges voiced by librarians in Downey's text: specifically, practicing critical pedagogy in the limited timeframe of a oneshot session.

\section{Advancing Critical Theory and Praxis}

In all four volumes, authors recognize, rely on, and draw inspiration from familiar cultural critics and educational theorists including Paulo Freire, Michel Foucault, Henry Giroux, bell hooks, Colin Lankshear, Michele Knoble, and Ira Shor. Freire is foundational throughout the four volumes and, to a lesser extent, so is Shor. Though Jack Mezirow figures prominently for Downey, he is seldom cited in the other texts, save in a chapter by LauBond. Several chapters in McNicol's book draw from Lankshear and Knoble, while hooks and Foucault appear most frequently in Pagowsky and McElroy's volumes.

The books differ in their definitions and interpretations of critical literacy and critical pedagogy. Both Downey and McNicol frame critical literacy using Ira Shor's 1999 article, "What is Critical Literacy?" Downey includes the fuller definition, which states that critical 
literacy may be employed in "questioning power relations, discourses, and identities in a world not yet finished, just, or humane" (p. 40), and that this questioning "challenges the status quo in an effort to discover alternative paths for self and social development" (Downey, 2016, p. 40; McNicol, 2016, p. xi). McNicol describes critical literacy as mindful of "social and cultural contexts," with a "focus on practical action and community engagement" and "issues of power" (xi). Here, the individual's adoption of a critical literacy lens commits them to "equity and social justice" (xi). Textual reading is central to McNicol's construction of critical literacy; text conveys meaning and the reading of texts produces meaning. Critical information literacy is also about reading texts, whether an article, an advertisement, a graph, or a video. These are all texts-representational forms of information-and "there is no single 'correct' way to read and respond" (McNicol, xii).

Downey outlines a hierarchy-an "educational critical theory umbrella" (p. 43)-wherein critical pedagogy and transformative learning are interchangeable, complementary, nested in experiential learning, and informed by critical theory. For McNicol and other authors in Critical Literacy for Information Professionals, critical literacy is an approach that places one in a critical stance and that complements a variety of theoretical perspectives: for example, reader-response, "includer" culture, and radical information literacy. McElroy and Pagowsky introduce their edited volumes by defining critical pedagogy as methods of teaching and learning that connect theory and practice in a reciprocal relationship: praxis. In their volumes, the contributing authors share works that "associate critical praxis with aspects of feminism, critical race theory, queer theory, disability studies, and other approaches that challenge hegemony" (p. xvii). Within and between these four texts, critical information literacy, critical literacy, and critical pedagogy are sometimes interchangeable, sometimes discrete, but always related. Regardless of the slippery relationships between these terms, Downey, McNicol, and McElroy and Pagowsky define critical pedagogical approaches as oriented toward action (change) and a more just world.

Librarians in each text express that the critical orientation of working toward a more just society makes their work more meaningful. Downey explains that librarians are drawn to CIL because it is "more in line with the values that drew them to librarianship in the first place" (p. 75). Values supported by the American Library Association, such as social responsibility, democracy, diversity, and the public good (ALA, 2004), guide librarians practicing in the United States, and critical librarianship aligns with these values. A number of international guidelines from the United Nations Educational, Scientific and Cultural Organization (UNESCO) and the International Federation of Library Associations and 
Institutions (IFLA) emphasize how libraries and librarians contribute to social justice work and include Beacons of the Information Society (UNESCO, 2005), Media and Information Literacy Recommendations (IFLA, 2011), and Access and Opportunity For All (IFLA, 2015).

Empowering the people who use libraries, in the struggle for social justice, is a significant theme that is present in all of the publications that we have reviewed in this essay. For McNicol, developing a critical literacy "may be powerful in providing readers with skills and strategies to challenge social and political systems" (p. 15). Thus, empowerment, in the case of critical practice, means cultivating the skills to transform those structures around us that contribute to inequality. In Pagowsky and McElroy's second volume, Noble urges librarians to "radically redefine the social structures that bolster systemic social inequality. It's time to bring new ideas and new paradigms of human dignity into the field of information studies" (p. xiv).

Librarians in each text identify serious issues that impede librarians' critical practice. Most complications occur in academic contexts. A lack of time to devote to critical teaching and learning practices is addressed implicitly or explicitly in all of these texts. A commitment to critical pedagogy requires invested time for instructional design, for learning, for reflection-both in the classroom and outside, for students and instructors-and for assessment or action research. It also takes time for librarians and faculty to develop trust and to navigate issues of "turf." Librarians may be presented as contingent, rather than integral, when their time with students is limited to the one-shots or to a few isolated information literacy sessions. The effect of neoliberalism in educational contexts contributes to an environment that supports a banking model of education and that critical practices seek to oppose. With all of these obstacles in place, we hear the collective asking, How can a critical practice be achieved? How do we "do critical pedagogy in the library" (Elmborg, xi)?

When taken together, these works succeed in demonstrating how librarians are experimenting with critical theory in their libraries and classrooms while resisting challenges to critical practice. These diverse voices, speaking from diverse contexts, show readers the multitude of ways in which praxis can be enacted, and together these texts advance CIL scholarship. Librarians will find inspiration in each text as they continue to develop a theoretically-informed praxis in libraries and with their communities. 


\section{Notes}

1. See http://critlib.org/twitter-chats/previous-twitter-chats/ for previous \#critlib chats.

2. Conscientization, or consciousness raising, is described by Kenny Garcia as, "the process of developing [a] complex understanding of oppression" in our world and learning to find ways to change systems of oppression (Pagowsky \& McElroy, 2016). In this case, critical librarians become aware of the structures of power-political, economic, social, and cultural-within which their work takes place. Critical librarians begin to recognize the part they play in perpetuating oppressive structures and systems, and work with other oppressed subjects to create change.

\section{References}

Accardi, M. T. (2013). Feminist pedagogy for library instruction. Sacramento, CA: Library Juice Press.

Accardi, M. T., Drabinski, E., \& Kumbier, A. (Eds.). (2010). Critical library instruction: Theories and methods. Duluth, MN: Library Juice Press.

American Library Association (ALA). (2004). Core values of librarianship. Retrieved from http://www.ala.org/advocacy/intfreedom/statementspols/corevalues

Andersen, J. (2006). The public sphere and discursive activities: Information literacy as sociopolitical skills. Journal of Documentation, 62(2), 213-228.

http://dx.doi.org/10.1108/00220410610653307

Association of College and Research Libraries (ACRL). (2015). Framework for information literacy for higher education. Retrieved from http://www.ala.org/acrl/standards/ilframework

Beatty, J. (2014). Locating information literacy within institutional oppression. In the Library with the Lead Pipe. Retrieved from http://www.inthelibrarywiththeleadpipe.org/2014/locating-information-literacy$\underline{\text { within-institutional-oppression/ }}$

Beilin, I., \& Leonard, A. (2013). Teaching the skills to question: A credit-course approach to critical information literacy. Urban Library Journal, 19(1), 1-10. 
Doherty, J. (2005). Towards self-reflection in librarianship: What is praxis? Progressive Librarian, (26), 11-17.

Doherty, J. (2007). No shhing: Giving voice to the silenced: An essay in support of critical information literacy. Library Philosophy and Practice, 9(3), 1-8.

Doherty, J., \& Ketchner, K. (2005). Empowering the intentional learner: A critical theory for information literacy instruction. Library Philosophy and Practice, 8(1).

Downey, A. (2016). Critical information literacy: Foundations, inspiration, and ideas. Sacramento, CA: Library Juice Press.

Drabinski, E. (2014). Toward a kairos of library instruction. Journal of Academic Librarianship, 40(5), 480-485. http://dx.doi.org/10.1016/j.acalib.2014.06.002

Elmborg, J. (2006). Critical information literacy: Implications for instructional practice. Journal of Academic Librarianship, 32(2), 192-199. http://dx.doi.org/10.1016/j.acalib.2005.12.004

Gregory, L., \& Higgins, S. (Eds.) (2013). Information literacy and social justice: Radical professional praxis. Sacramento, CA: Library Juice Press.

Hicks, A. (2013). Cultural shifts: Putting critical information literacy into practice. Communications in Information Literacy, 7(1), 51-65.

International Federation of Library Associations and Institutions (IFLA). (2015). Access and opportunity for all: How libraries contribute to the United Nations 2030 agenda. Retrieved from https://www.ifla.org/publications/node/10546

International Federation of Library Associations and Institutions (IFLA). (2011). IFLA Media and information literacy recommendations. Retrieved from https://www.ifla.org/publications/ifla-media-and-information-literacyrecommendations

Jacobs, H. L. (2008). Information literacy and reflective pedagogical praxis. Journal of Academic Librarianship, 34(3), 256-262. http://dx.doi.org/10.1016/j.acalib.2008.03.009

Kapitzke, C. (2003). Information literacy: A review and post structural critique. Australian Journal of Language and Literacy, 26(1), 53-66. 
Leckie, G. J., Given, L. M., \& Buschman, J. (Eds.). (2010). Critical theory for library and information science: Exploring the social from across the disciplines. Santa Barbara, CA: Libraries Unlimited.

Luke, A., \& Kapitzke, C. (1999). Literacies and libraries: Archives and cybraries. Pedagogy, Culture and Society, 7(3), 467-491. http://dx.doi.org/10.1080/14681369900200066

McNicol, S. (Ed.). (2016). Critical literacy for information professionals. London, England: Facet Publishing.

Morrone, M. (Ed.). (2013). Informed agitation: Library and information skills in social justice movements and beyond. Sacramento, CA: Library Juice Press.

Nicholson, K. (2014). Information literacy as a situated practice in the neoliberal university. Proceedings of the Annual Conference of the Canadian Association for Information Science. Retrieved from http://www.cais-acsi.ca/ojs/index.php/cais/article/view/901

Pagowsky, N., \& McElroy, K. (Eds.). (2016). Critical library pedagogy handbook (Vols. 1-2). Chicago, IL: Association of College and Research Libraries.

Pawley, C. (1998). Hegemony's handmaid? The library and information studies curriculum from a class perspective. The Library Quarterly, 68(2), 123-144. http://dx.doi.org/10.1086/602955

Pawley, C. (2003). Information literacy: A contradictory coupling. The Library Quarterly: Information, Community, Policy, 73(4), 422-452. http://dx.doi.org/10.1086/603440

Reale, M. (2012). Critical pedagogy in the classroom: Library instruction that gives voice to students and builds a community of scholars. Journal of Library Innovation, 3(2), 80-88.

Schlesselman-Tarango, G. (2014). Cyborgs in the academic library: A cyberfeminist approach to information literacy instruction. Behavioral $\&$ Social Sciences Librarian, 33(1), 29-46. http://dx.doi.org/10.1080/01639269.2014.872529

Schroeder, R. (2014). Critical journeys: How 14 librarians came to embrace critical practice. Sacramento, CA: Library Juice Press.

Simmons, M. H. (2005). Librarians as disciplinary discourse mediators: Using genre theory to move toward critical information literacy. portal: Libraries and the Academy, 5(3), 297311. http://dx.doi.org/10.1353/pla.2005.0041 
Smith, L. (2013). Towards a model of critical information literacy instruction for the development of political agency. Journal of Information Literacy, 7(2), 15-32.

http://dx.doi.org/10.11645/7.2.1809

Swanson, T. A. (2004). A radical step: Implementing a critical information literacy model. portal: Libraries and the Academy, 4(2), 259-273. http://dx.doi.org/10.1353/pla.2004.0038

United Nations Educational, Scientific and Cultural Organization (UNESCO) \& International Federation of Library Associations and Institutions (IFLA). (2005). Beacons of the information society: The Alexandria proclamation for information literacy and lifelong learning. Retrieved from http://www.unesco.org/fileadmin/MULTIMEDIA/HQ/CI/CI/pdf/alexandria_proclam ation_info_literacy.pdf

Whitworth, A. (2006). Communicative competence in the information age: Towards a critical theory of information literacy education. Innovation in Teaching and Learning in Information and Computer Sciences, 5(1), 1-13. 